\title{
William Gordon, B.Sc. (Eng.), Ph.D., M.I.Mech.E.
}

Dr William Gordon, Lecturer on Strength of Materials in the University of Edinburgh, died unexpectedly on 22nd May 1932, after a short illness.

William Gordon had inherited his engineering tendencies from his father, who was a civil engineer in Messrs Stevenson's office, Edinburgh. His professional education began in Lockie's Academy of Engineering, Leith, before the foundation of Leith Technical College. For a brief period he was a student of engineering in the University of Edinburgh, in Professor Armstrong's time, and served his apprenticeship at Messrs James Milne \& Sons (Ltd.), general engineers. He devoted himself to the mechanical side of the profession, and found his chief interest in the strength of materials. He joined the staff of Leith Technical College, and soon became chief lecturer in Mechanical Engineering. He held this appointment for over thirty years, throughout the famous days of Principal Bolam, and produced a high standard of work.

Returning to Edinburgh University fairly late in life, he graduated B.Sc.(Eng.) in 1911, under Professor Sir Thomas Hudson Beare. The years 1911-13 were occupied by research work on the strength of materials, under, and in conjunction with, Dr Gulliver. When Dr Gulliver left Edinburgh University to become head of Kirkaldy's testing laboratories (Southwark, London), Mr Gordon succeeded him as assistant in Engineering, and was appointed Lecturer in Forest Engineering.

Mr Gordon visited Germany in 1914, immediately before the outbreak of war, and on his return, though he was unfit for active service in the field, he applied for and was granted a commission in the Royal Field Artillery (T.F.). During the War, in addition to his University duties, he did valuable work with the University Battery of the Officers' Training Corps.

In 1919, when the Engineering Departinent was reorganised and extended after the War, he resigned Forest Engineering, and was appointed University Lecturer in Strength of Materials, with charge of the laboratory. This position he held to the end of his life. He had continued his research work, and became Ph.D. in 1925. When the Engineering Department was transferred from High School Yards to King's Buildings in 1931, Dr Gordon was in charge of the arrangements for the new Strength of Materials Laboratory. During his University career he carried out-in addition to 
his ordinary duties-a vast amount of testing of the materials of construction for all sorts of purposes.

Dr Gordon published various papers, some of which were in conjunction with Dr Gulliver, and one with Sir Thomas Hudson Beare. These appeared in Proc. Roy. Soc. Edin., the Brit. Assoc., and the Revue de Metallurgie. The subjects dealt chiefly with the Strength of Materials. He was specially interested in the behaviour of flat steel bars, and got, with some trouble, an 'ideal' structural steel cast specially for his investigations. Accuracy in measurement appealed to him, and he endeavoured to base his work on mathematical methods.

He was a splendid teacher and full of enthusiasm for his subject. His devotion to the University was whole-hearted, it was the chief interest of his life. Combining as he did the two positions of lecturer in a University and in a Technical College, he was a thorough believer in the importance of each, but held strongly that Universities and Technical Colleges supplied different needs, and that their aims and spheres of action should be kept distinct.

Gordon combined the intense practicality of the engineer with a speculative and philosophic mind. This kept him far from narrow views. He read widely, and in his later years became much interested in architecture and archæology. A versatile talker, his conversation was enhanced by an amazing gift of mimicry. His death is deeply regretted by a wide circle of friends, and by none more than by his colleagues in the Department of Engineering.

He was elected a Fellow of the Society in 1920.

E. M. H. 